\title{
P2M PELATIHAN PEMBUATAN MOU \\ POKDARWIS TUNJUNG MEKAR \\ DI DESA SAMBANGAN
}

\author{
oleh, \\ Nyoman Dini Andiani \\ Jurusan Managemen Pariwisata \\ Fakultas Ekonomi dan Bisnis \\ Universitas Pendidikan Ganesha
}

\begin{abstract}
ABSTRAK
Kegiatan Pengabdian Pada Masyarakat (P2M) yang dilaksanakan ini bertujuan untuk memberikan pelatihan pembuatan contract agreement latter kepada anggota POKDARWIS Tunjung Mekar, sebagai langkah awal menciptakan kerjasama yang profesional antara pihak pengelola potensi Desa Sambangan dengan pihak travel perjalanan wisata, yang nantinya akan membawa wisatawan untuk berkunjung ke Desa Sambangan. Selain sebagai suatu ikatan kerjasama, adanya MOU ini, merupakan satu kesatuan sales kit. Metode yang digunakan dalam Program Pengabdian pada Masyarakat ini adalah metode kerja kolaborasi antara dosen, dan masyarakat sasaran (dalam hal ini adalah anggota POKDARWIS Tunjung Mekar). Di samping itu, dalam melaksanakan Program Pengabdian pada Masyarakat ini, tim P2M juga menggunakan metode observasi, metode penyuluhan dan pelatihan, serta metode wawancara dan evaluasi kegiatan.
\end{abstract}

Kata-kata Kunci : Pengabdian, MOU

\section{Pendahuluan}

Desa Sambangan terletak di Kecamatan Sukasada, Kabupaten Buleleng. Dari Denpasar, Desa Sambangan dapat dicapai dengan menempuh jalur Denpasar-Singaraja, dalam waktu sekitar 2,5 jam. Wilayah Desa Sambangan sebagian besar merupakan kawasan pemukiman yang berbatasan dengan persawahan serta hutan lindung di bagian hulunya (sebelah selatan desa). Topografi Desa Sambangan cukup bervariasi. Wilayah bagian bawah (utara) desa relatif datar, sedangkan di beberapa lokasi lain, antara lain di sekitar pegunungan yang berbatasan dengan Desa Wanagiri (sebelah selatan Desa Sambangan), wilayahnya relatif terjal dengan kemiringan lereng lebih dari $40 \%$. Ketinggian di wilayah tersebut mencapai sekitar 500m - 1.020m di atas permukaan laut (dpl). Sementara sebagian wilayah di Desa Wanagiri bahkan dapat mencapai ketinggian 1.350m dpl (peta rupa bumi Digital Indonesia, 1999). Berdasarkan pencatatan di Stasiun 
Candi Kuning, rata-rata suhu udara bulanan di Desa Sambangan berkisar antara $10^{\circ} \mathrm{C}$ dan $14^{0} \mathrm{C}$, sementara suhu bulanan maksimumnya berkisar antara $21{ }^{0} \mathrm{C}$ dan $25^{\circ} \mathrm{C}$.

Objek wisata alam air terjun di Desa Sambangan ini dikelola oleh masyarakat setempat dalam suatu wadah organisasi yang bernama Kelompok Sadar Wisata (POKDARWIS) Tunjung Mekar. Keberadaan organisasi ini telah mendapat perhatian dari berbagai kalangan baik itu pihak pemerintah setempat dalam hal ini Dinas Pariwisata Daerah Kabupaten Buleleng dan kalangan akademisi. Melalui program P2M Dana Dipa 2011, penulis telah melakukan pengabdian pada masyarakat dengan melibatkan Kelompok Sadar Wisata (POKDARWIS) Tunjung Mekar sebagai mitra dalam melakukan kegiatan pelatihan penyusunan design peta paket wisata. Pelatihan ini telah menghasilkan pemetaan terhadap potensi yang dimiliki Desa Sambangan yang dituangkan dalam suatu brosur, brosur ini merupakan salah satu media promosi yang akan dibagikan ke setiap BPW. Menindaklanjuti media promosi yang telah di hasilkan sebelumnya, maka diperlukannya pelatihan lebih lanjut prihal pembuatan draft surat kontrak atau contract agreement letter dan pembutan video singkat yang nantinya bisa menjadi satu kesatuan sales kit pada saat menawarkan potensi Desa Sambangan ke BPW secara lebih professional. Melalui pengajuan proposal P2M ini diharapkan bisa merealisasikan apa yang menjadi kebutuhan POKDARWIS Tunjung Mekar dalam meningkatkan pangsa pasar wisatawan yang berkunjung, sehingga mampu meningkatkan pendapatan masyarakat sekitar. Adapun keberlanjutan dari program ini adalah dengan kerjasama yang baik dengan pihak BPW nantinya, POKDARWIS Tunjung Mekar bisa diberikan pembinaan dan pelatihan technique guiding dan managemen pengelolaan yang professional..

Pengembangan potensi wisata Sambangan sebenarnya telah ditindaklanjuti dengan memaksimalkan partisipasi berbagai stakeholders yang ada seperti; Adat, BPD, dan LPM. Realisasi dari pelembagaan itu disepakati dengan menugaskan Made Widana sebagai Ketua POKDARWIS (Kelompok Sadar Wisata) yang dibentuk pada tahun 2004, untuk melakukan berbagai upaya demi memajukan dan mengembangkan potensi wisata yang ada. Hal ini juga mendapat respon positif dari berbagai pihak, baik dari pemerintah maupun masyarakat. Dalam hal ini, pemerintah melalui Dinas Kehutanan Provinsi Bali dan Kabupaten Buleleng memberikan dukungan dalam program reboisasi. 
Sementara masyarakat lokal melalui tokoh (elite) Desa Sambangan memiliki keinginan yang kuat untuk mengembangan potensi ekowisata yang dimilikinya. Hal ini tampak dari keseriusan, semangat, dan upaya yang dilakukan Kelompok Sadar Wisata Tanjung Mekar dan tokoh masyarakat yang ada di Desa Sambangan.

Jika dikaitkan dengan siklus hidup daerah pariwisata yang dikemukakan oleh Butler, pengembangan objek wisata, berupa air terjun (air terjung Aling-Aling, air terjun dedari, air terjun Canging, air terjun Cemare) di Desa Sambangan baru termasuk dalam tahap ekplorasi (pertumbuhan). Kondisi tersebut menunjukkan bahwa objek wisata air terjun tersebut masih memiliki kesempatan serta peluang yang besar untuk terus dikembangkan. Beberapa hal yang dapat dilakukan terkait dengan hal ini adalah dengan usaha peningkatan kerjasama dengan para BPW yang dilandasi dengan system kerjasama yang professional. Dalam hal ini, salah satu upaya yang dapat dilakukan sebagai wujud pengabdian pada masyarakat yang bisa dilakukan yaitu dengan memberikan pelatihan pembuatan MOU.

Analisis situasi pada POKDARWIS Tunjung Mekar di Desa Sambangan menunjukan bahwa pengembangan objek wisata yang ditawarkan kepada wisatawan masih mengalami berbagai kendala. Dengan kualifikasi pendidikan dan tingkat kemampuan yang ditunjukan pada tabel 1, mengindikasikan bahwa kemampuan ketua dan anggota POKDARWIS dalam membuat surat kerjasama dan video sebagai sarana mediasi dalam promosi, belum bisa dilakukan, sehingga hal ini bisa merupakan salah satu hambatan untuk bisa memberikan informasi yang tepat. Adapun tingkat jumlah kunjungan wisatawan ke Desa Sambangan yang ditangani langsung oleh anggota POKDARWIS Tunjung Mekar dapat dilihat pada tabel 1.

Tabel 1

Rekapitulasi Perkembangan Kunjungan Wisman dan Wisdom Pada Objek dan Daya Tarik Air Terjun di Desa Sambangan Tahun 2001-2010

\begin{tabular}{|l|c|c|c|c|}
\hline \multirow{2}{*}{ No } & Tahun & \multicolumn{3}{|c|}{ Jumlah Kunjungan } \\
\cline { 3 - 5 } & & $\begin{array}{c}\text { Wisatawan } \\
\text { Mancanegara }\end{array}$ & $\begin{array}{c}\text { Wisatawan } \\
\text { Domestik }\end{array}$ & Jumlah \\
\hline 1 & 2005 & 92 & 703 & 795 \\
\hline 2 & 2006 & 149 & 558 & 807 \\
\hline 3 & 2007 & 156 & 146 & 302 \\
\hline 4 & 2008 & 209 & 437 & 646 \\
\hline 5 & 2009 & 252 & 213 & 465 \\
\hline 6 & 2010 & 235 & 305 & 540 \\
\hline
\end{tabular}


Sumber : Data Olahan Dari POKDARWIS Tunjung Mekar, 2010

Tabel 2 menunjukan bahwa tingkat kunjungan wisatawan mengalami tingkat fluktuasi, pada tahun 2005 menunjukan tingkat kunjungan dari wisatawan domestik yang memiliki perbandingan signifikan dengan kedatangan tamu mancanegara, karena wisatawan domestik yang kebanyakan datang berkunjung adalah berasal dari sekolahsekolah serta dari aktivis pencinta alam. Kondisi tersebut menunjukan bahwa pihak pengelola belum mampu melakukan kegiatan promosi baik itu dalam rangka meningkatkan tingkat kunjungan wisatawan domestik ataupun wisatawan mancanegara. Tingkat kunjungan yang rendah yang dialami oleh kelompok POKDARWIS Tunjung Mekar disebabkan oleh (1) tingkat pengetahuan dan kemampuan dalam melakukan kerjasam dengan pihak BPW belum pernah dilakukan, (2) Kurangnya media promosi visual seperti video, (3) tidak memiliki buku panduan (guiding book) dalam bahasa inggris, (4) belum memiliki pengetahuan tentang pengemasan produk paket wisata alternative.

Berdasarkan uraian tersebut di atas, maka untuk mampu mengembangkan kemampuan para anggota dari Kelompok Sadar Wisata Tunjung Mekar dalam meningkatkan kerjasama dengan BPW dan mempromosikan potensi pariwisata alam yang ada di Desa Sambangan, maka pelatihan yang mendasar yang perlu di berikan kembali kepada kelompok ini adalah pelatihan pembuatan surat kerjasama (MOU) dengan para BPW, dan pembinaan dalam pembuatan media audio visual berupa video potensi, sehingga nantinya mampu menghasilkan peningkatan kunjungan melalui kerjasama dan media promosi yang profesional.

\section{Metode Pelaksanaan Pengabdian}

Metode yang digunakan dalam Program Pengabdian pada Masyarakat ini adalah metode kerja kolaborasi antara dosen, dan masyarakat sasaran (dalam hal ini adalah anggota POKDARWIS Tunjung Mekar), serta berbagai pihak yang mendukung pelaksanaan program. Di samping itu, dalam melaksanakan Program Pengabdian pada Masyarakat ini, penulis juga menggunakan metode sebagai berikut.

Metode Observasi: melalui metode ini, penulis melaksanakan kegiatan observasi ke objek wisata yang ada di Desa Sambangan. Kegiatan observasi ini dilaksanakan untuk 
mengumpulkan data dan memperoleh gambaran umum tentang paket wisata dan harga yang nantinya akan dimasukan dan surat perjanjian dengan pihak BPW. Kegiatan observasi ini terus dilakukan secara berkelanjutan. Observasi juga dilakukan setelah melakukan pelatihan untuk memperoleh informasi tindak lanjut kegiatan yang dilakukan masyarakat dari hasil pelatihan.

Metode Penyuluhan dan Pelatihan: untuk memberikan pengetahuan dan pemahaman dasar kepada anggota POKDARWIS Tunjung Mekar terkait dengan pentingnya MOU dengan pihak BPW, tim P2M melakukan kegiatan penyuluhan dan pelatihan. Kegiatan ini dilaksanakan di Desa Sambangan mulai dari pembekalan pada bulan Juni dan lanjut pada tahapan pelatihan di bulan Agustus. Peserta pelatihan berasal dari anggota POKDARWIS Tunjung Mekar yang terdiri dari kelompok 2 kelompok, sebanyak 20 orang.

Metode Wawancara: dalam pelaksanaan Program Pengabdian pada Masyarakat ini, metode wawancara dilaksanakan sebagai sarana evaluasi kegiatan. Wawancara dilaksanakan dengan ketua POKDARWI Tunjung Mekar Komang Roy Prismayudi untuk memperoleh gambaran tentang kepengurusan dan program kegiatan POKDARWIS Tunjung Mekar selama ini. Di samping itu, wawancara juga dilaksanakan dengan anggota POKDARWIS Tunjung Mekar yang menjadi peserta pelatihan, untuk mengetahui tanggapan dan antusiasme peserta terhadap kegiatan yang dilaksanakan, sekaligus menampung saran-saran yang diberikan kepada tim P2M selaku pelaksana kegiatan sebagai bahan evaluasi untuk kegiatan selanjutnya.

\section{Hasil dan Pembahasan}

Secara struktural jumlah anggota POKDARWIS berjumlah 30 orang, namun yang aktif dalam berbagai kegiatan pelaksanaan secara teknis di lapangan hanya 20 orang saja. Sedangkan untuk pendapatan anggota POKDARWIS yang 90\% adalah petani, menunjukan bahwa anggota POKDARWIS lebih terkosentrasi dalam menggarap sawahnya, dibandingkan meningkatkan jumlah kunjungan wisatawan ke desanya. Hal ini tentunya disebabkan oleh tingkat kemampuan anggota POKDARWIS, yang kebanyakan belum pada tahap melakukan tugas struktural organisasi seperti melakukan kegiatan pemasaran, atau apalagi pada tahap pembuatan desain peta paket wisata sebagai media promosi. Dapat diketahui pada tabel 2 hanya 4 orang yang mampu 
menguasai bahasa asing (bahasa inggris) dan hanya 2 orang yang memiliki keterampilan dalam menggunakan media elektronik yaitu komputer.

Tabel 2

Daftar nama-nama anggota POKDARWIS yang memiliki kemampuan khusus

\begin{tabular}{|l|l|c|c|}
\hline \multirow{2}{*}{ No. } & \multicolumn{2}{|c|}{ Nama } & \multicolumn{2}{c|}{ Nama Keahlian } \\
\cline { 3 - 4 } & & Komputer & Bahasa Inggris \\
\hline 1 & Darmada & $\sqrt{ }$ & $\sqrt{ }$ \\
\hline 2 & Made Widana & & $\sqrt{ }$ \\
\hline 3 & Komang Sutrisna & & $\sqrt{ }$ \\
\hline 4 & Kadek Adi Sucipta & & $\sqrt{ }$ \\
\hline
\end{tabular}

(Sumber : Olahan Data, 2011)

Dengan kualifikasi pendidikan dan tingkat kemampuan yang ditunjukan pada tabel 2, mengindikasikan bahwa kemampuan anggota POKDARWIS dalam memberikan pelayan komunikasi dan media informasi mengenai potensi objek yang dimiliki kepada calon wisatawan belum bisa diakomodir dengan baik, sehingga hal ini bisa merupakan salah satu hambatan untuk bisa memberikan kepuasan kepada wisatawan. Pelaksanaan program Pengabdian pada Masyarakat tentang pelatihan pembuatan desain peta paket wisata bagi anggota POKDARWIS Tunjung Mekar dilaksanakan berdasarkan metode dan tahap yang telah direncanakan sebelumnya. Jumlah peserta pelatihan pada kegiatan ini adalah sebanyak 20 orang yang seluruhnya berasal dari anggota POKDARWIS Tunjung Mekar. Secara teknis, 20 orang tersebut dibagi menjadi 2 (dua) kelompok utama, yakni kelompok pengelola objek air terjun Aling-Aling dan kelompok pengelola objek air terjun Cemare. Jumlah peserta yang hanya 20 orang didasarkan pada pertimbangan agar kegiatan pelatihan dapat dilaksanakan secara efektif dan efisien. Hal ini mengingat jenis pelatihan yang dilakukan memang harus dikuasai secara bertahap dan detail, sehingga diperoleh hasil pelatihan yang maksimal, dan tujuan yang diharapkan dapat tercapai. Daftar nama peserta pelatihan disajikan dalam tabel 3 .

Tabel 3.

Nama Anggota POKDARWIS Tunjung Mekar Peserta P2M

\begin{tabular}{|c|l|c|}
\hline No. & \multicolumn{1}{|c|}{ Nama } & Pendidikan Terakhir \\
\hline 1 & Wayan Dapet & SD \\
\hline 2 & Mudiasta & SD \\
\hline 3 & Luh Wiratmi & SMP \\
\hline
\end{tabular}




\begin{tabular}{|c|l|l|}
\hline 4 & Gede Agus Suparma & SMU \\
\hline 5 & Made Widana & SMU \\
\hline 6 & Putu Wirawan & SMU \\
\hline 7 & Ketut Reksanadana & SMU \\
\hline 8 & Ketut Putra & SMU \\
\hline 9 & Kadek Ari Prabudi & SMU \\
\hline 10 & Kadek Adi Sucipta & SMU \\
\hline 11 & Kadek Marisni & SMU \\
\hline 12 & Putu Puspa & SMU \\
\hline 13 & Made Suksa & SMU \\
\hline 14 & Ketut Wiriyasa & SMU \\
\hline 15 & Komang Sutrisna & SMU \\
\hline 16 & Made Artawa & SMU \\
\hline 17 & Ketut Toya & SMU \\
\hline 18 & Ketut Sadia Ardana & SMU \\
\hline 19 & Made Dana & SMU \\
\hline 20 & Putu Witama & SMU \\
\hline
\end{tabular}

Yang menjadi tim pelaksana kegiatan pelatihan P2M ini adalah Tim Dosen 3 orang. Untuk memecahkan masalah yang dialami mitra tim pelaksana P2M akan melakukan beberapa pendekatan terlebih dahulu, adapun pendekatan yang dilakukan untuk mendukung realisasi Program P2M dalam memecahkan masalah di kelompok POKDARWIS di Desa Sambangan Kecamatan Sukasada Kabupaten Buleleng, adalah memberikan pemahaman lebih dalam tentang pentingnya pembuatan surat perjanjian, lalu memberikan pengenalan tentang penyusunan draft surat perjanjian, dilanjutkan dengan pelatihan aplikasi pembuatan draft surat perjanjian dalam bahasa inggris dan bahasa Indonesia dan sekaligus pembinaan kombinasi pemunculan paket wisata dalam video yang akan dibuat dalam program selanjutnya. Apabila pemahaman tersebut telah dimiliki maka perlu dilakukan pendampingan implementasi pembuatan MOU dan video. Sampai pada tahap akhir yaitu melakukan refleksi kembali serta penyempurnaan terhadap program yang telah dibuat yang akan ditindak lanjuti dengan menyeleksi beberapa anggota yang selama pelatihan memiliki kemampuan maksimal dan interest yang tinggi untuk mamdi tingkat managemen

Pelatihan keterampilan penyusunan surat perjanjian atau MOU pada POKDARWIS di Desa Sambangan, Kabupaten Buleleng Bali menargetkan luaran berupa kemampuan anggota POKDARWIS Tunjung Mekar dalam penyusunan surat perjanjian kerjasama yang nantinya akan menghasilkan draft surat kerjasama / MOU baik dalam bahas 
Indonesia ataupun bahasa Inggris sebagai acuan dalam membuat kerjasama selanjutnya dengan para BPW. Melalui pembinaan pentingnya pembuatan video sebagai media promosi audio visual akan menghasilkan rancangan paket paket wisata yang akan dimasukan dalam kemasan video singkat tersebut termasuk dengan narasi yang lengkap di dalamnnya dalam bahasa inggris. Adapun rincian luaran yang telah dicapai adalah sebagai berikut. (1) Melalui Pelatihan anggota POKDARWIS mampu menghasilkan draf surat perjanjian kerjasama (MOU) dalam bahasa Inggris, yang di dalam surat tersebut berisikan aturan selama mengikuti kegiatan di Objek Wisata Alam Desa Sambangan dan berikan daftar paket serta harga setiap kegiatan wisata adventure ataupun wisata treking yang dilakukan. (2) Melalui pembinaan pentingnya media audio visual (video) sebagai alat promosi, maka secara tidak langsung melalui pembinaan tersebut anggota POKDARWIS tidak hanya memiliki pengetahuan tentang pentingnya media promosi ini, akan tetapi bisa menghasilkan rancangan awal paket wisata serta narasi yang akan dimasukan dalam pembuatana video tersebut.

Selama melaksanakan kegiatan Pengabdian pada Masyarakat ini, penulis memiliki kendala terkait dengan teknis pelaksanaan kegiatan. Hambatan yang terjadi antara lain adalah frekuensi kehadiran peserta yang tidak maksimal. Selama kegiatan berlangsung, banyak peserta pelatihan yang tidak dapat mengikuti kegiatan secara penuh. Hal ini disebabkan karena adanya kegiatan-kegiatan lain oleh peserta yang waktunya berbenturan dengan kegiatan pelatihan. Di samping itu, rata-rata tingkat kemampuan (daya serap) peserta tentang cara pembuatan MOU yang terkait dengan penentuan kebijakan masalah harga sangat sulit mencapai kesepakatan.

\section{Penutup}

Pelaksanaan program Pengabdian pada Masyarakat tentang pelatihan pembuatan MOU dengan sasaran strategis dalam pelaksanaan P2M ini adalah anggota POKDARWIS Tunjung Mekar, pemberian pelatihan terhadap 20 orang anggota ini telah memberikan pengetahuan dan keahlian dalam membuat dan merancang surat kesepakatan bersama. Partisipasi mitra yaitu anggota POKDARWIS dalam pelatihan dengan jumlah peserta pelatihan 20 orang, merupakan pertimbangan untuk mampu 
mengefektiffkan proses pelatihan, mengingat jenis pelatihan yang dilakukan merupakan penerapan penyusunan berbagai aspek perjanjian termasuk penyusunan harga yang harus dikuasai secara bertahap dan detail, untuk memperoleh hasil pelatihan yang maksimal, yang nantinya mampu menghasilkan tujuan yang diharapkan. Dengan beberapa tahapan - tahapan kegiatan yang telah di paparkan, dan tim pelaksanapun akan melakukan tahapan identifikasi kebutuhan serta melakukan refleksi pelaksanaan program yang didampingi oleh Tim dosen penyelenggara. Dari kegiatan yang telah dilaksanakan, secara umum luaran yang diharapkan telah tercapai yaitu berupa Draft MOU dan video amatir audio visual tentang potensi air terjun di Desa Sambangan.

\section{DAFTAR PUSTAKA}

Anonim. 2006. Data Monografi Desa dan Kelurahan Sambangan, Kabupaten Buleleng.

Dalem, A. A. G. R. 2004a. Merumuskan prinsip-prinsip dan kriteria ekowisata daerah Bali. Jurnal Lingkungan Hidup Bumi Lestari 4 (2) : 86 - 90

Dalem, A. A. G. R. 2004b. Ekowisata dan agrowisata. Makalah disampaikan pada penataran Kelompok Sadar Wiasata Denpasar tanggal 25-31 Juli 2004. Sebagian besar isi makalah ini pernah disampaikan dalam seminar "Dengan Ekowisata Menuju Pembangunan Pariwisata Berkelanjutan" di Auditorium Universitas Udayana Denpasar, 29 Juni 2002.

Kartajaya, Hermawan. 2003. Marketing in Venus. Jakarta: PT Gramedia Pustaka Utama Kotler, P \& Bowen, J.T. \& Makens J.C. 2006. Marketing for hospitality and tourism, Pearson Education, Inc., New Jersey.

Pendit, Nyoman. 1999. Ilmu Pariwisata sebuah pengantar perdana. Jakarta: PT. Pradnya Paramita.

STP Bali. 2000. Evaluasi Produk Wisata Air Terjun Sambangan Kecamatan Sukasada Kabupaten Buleleng Propinsi Bali. STP: Nusa Dua Bali

Sudibya, Bagus, 2003, Prospektif Agrowisata dan Ekowisata di Kabupaten Buleleng Propinsi Bali (Makalah ini disampaikan pada Seminar menjadikan Buleleng sebagai Daerah Tujuan Wisata Agrotourisme dan Ekotourisme pada tanggal 25 Agustus 2003).

Wahab, Salah, 1989, Pemasaran Pariwisata, Jakarta : PT Pradnya Paramita.

Wiratno. 2. Model Analisis Dalam Pengembangan Wisata Alam. Yogyakarta. Pustaka Pelajar Offset 